Article

\title{
Removal of Trace Thallium from Industrial Wastewater by $\mathrm{Fe}^{0}$-Electrocoagulation
}

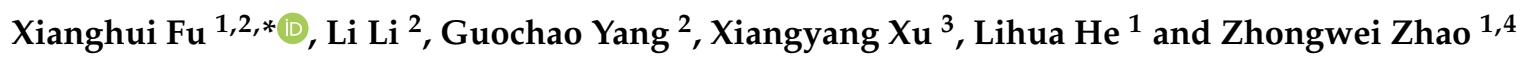 \\ 1 School of Metallurgy and Environment, Central South University, Changsha 410083, China; \\ helihua@csu.edu.cn (L.H.); zhaozw@csu.edu.cn (Z.Z.) \\ 2 Changsha Research Institute of Mining and Metallurgy Co. Ltd., Changsha 410012, China; \\ lilicsy15@outlook.com (L.L.); porky770125@outlook.com (G.Y.) \\ 3 School of Minerals Processing and Bioengineering, Central South University, Changsha 410083, China; \\ xuxiangyang@csu.edu.cn \\ 4 Key Laboratory of Hunan Province for Metallurgy and Material Processing of Rare Metals, \\ Changsha 410083, China \\ * Correspondence: fuxh@csu.edu.cn
}

Received: 27 November 2019; Accepted: 2 January 2020; Published: 5 January 2020

\begin{abstract}
As thallium ( $\mathrm{Tl}$ ) is a highly toxic heavy metal, there are compulsory environmental regulations in many countries on minimizing its release. This research investigated the treatment of real industrial wastewater with low $\mathrm{Tl}(\mathrm{I})$ concentration by $\mathrm{Fe}^{0}$-electrocoagulation $\left(\mathrm{Fe}^{0}-\mathrm{EC}\right)$ in a batch aeration-forced pump cycle reactor. The effects of $\mathrm{pH}(7-12)$, current density $\left(8.3-33.3 \mathrm{~mA} / \mathrm{cm}^{2}\right)$, dissolved oxygen (DO) in wastewater, and initial Tl(I) concentration $(66-165 \mu \mathrm{g} / \mathrm{L})$ on $\mathrm{Tl}(\mathrm{I})$ removal efficiency were investigated. The removal efficiency of $\mathrm{Tl}(\mathrm{I})$ is $\mathrm{pH}$-dependent, to be exact, it increases significantly with $\mathrm{pH}$ rising from 8 to 11 . Initial $\mathrm{pH}$ of influent and $\mathrm{DO}$ concentration were the key operation parameters which strongly affect $\mathrm{Tl}(\mathrm{I})$ removal. After the water sample with initial $\mathrm{Tl}(\mathrm{I})$ concentration of $115 \mu \mathrm{g} / \mathrm{L}$ was treated for $12 \mathrm{~min}$ by a single-step process at $\mathrm{pH}$ of 11 and current density of $16.7 \mathrm{~mA} / \mathrm{cm}^{2}$, the residual $\mathrm{Tl}(\mathrm{I})$ concentration was decreased to beneath the emission limit in China $(2 \mu \mathrm{g} / \mathrm{L})$ with a low energy consumption of $0.82 \mathrm{kWh} / \mathrm{m}^{3}$. By prolonging the operation time, the concentration was further reduced to $0.5 \mu \mathrm{g} / \mathrm{L}$ or even lower. The main composition of the flocculent sludges is iron oxyhydroxide, yet its crystal structure varies dependent on $\mathrm{pH}$ value which may result in different $\mathrm{Tl}(\mathrm{I})$ removal efficiency. Feroxyhyte nanosheets generate in situ by $\mathrm{Fe}^{0}$-EC, which contributes to the rapid and effective removal of $\mathrm{Tl}(\mathrm{I})$, while the speedy oxidation under DO-enriched conditions benefits the feroxyhyte formation. The mechanism of Tl(I) removal by $\mathrm{Fe}^{0}$-EC is attributed to the combination of electrostatic attraction and the formation of inner-sphere complexes. As shown in the technical and mechanical studies, $\mathrm{Fe}^{0}-\mathrm{EC}$ technology is an effective method for low $\mathrm{Tl}$ concentration removal from wastewater.
\end{abstract}

Keywords: thallium; electrocoagulation; industrial wastewater; iron electrodes; dissolved oxygen; feroxyhyte

\section{Introduction}

Thallium (Tl) is a rare but widely dispersed element with high toxicity. Because of its high acute toxicity to living organisms and its irreversible biological toxicity and strong bioaccumulation [1,2], $\mathrm{Tl}$ and its compounds are considered as the main hazardous wastes by the World Health Organization [3]. It has been classified as a priority pollutant by the United States Environmental Protection Agency (USEPA) [4] and the European Union Water Framework Directive [5]. It has also been listed by China as one of the key heavy metal pollutants [6]. The concentration of $\mathrm{Tl}$ in the natural environment is 
usually remarkably low, which makes it challenging to evaluate its quantity precisely [2] and to remove it effectively [7]. Because of this, $\mathrm{Tl}$ has been studied much less than other toxic elements such as $\mathrm{Cr}$, As, or $\mathrm{Cd}$. Owing to the increasing consumption of $\mathrm{Tl}$ and its compounds, $\mathrm{Tl}$ is now a new emerging element which has become an unneglectable burden on the environment [8-10].

Tl belongs to Group 13 of the periodic table of the elements sitting, and it can exist in aqueous solutions mainly in two oxidation states, $\mathrm{Tl}(\mathrm{III})$ and $\mathrm{Tl}(\mathrm{I})$ [11]. Tl(III) usually exists in water such as lake water or marsh water, which is rich in colloids and organic matter [12]. Yet, under normal circumstances, $\mathrm{Tl}(\mathrm{III})$ is converted to a monovalent state as it possesses a strong oxidizing tendency [13]. So, in most natural environments, thallous compounds are the dominant species [14]. $\mathrm{Tl}(\mathrm{I})$ is soluble as the species of $\mathrm{Tl}(\mathrm{I})$ cation or $\mathrm{TlOH}_{(\mathrm{aq})}$ at a wide $\mathrm{pH}$ range of 0-14 [7], which suggests that the conventional approaches, such as co-precipitation to remove of heavy metals from wastewater might be invalid when processing $\mathrm{Tl}(\mathrm{I})$.

Currently available methods for Tl removal mainly include adsorption [15-18], oxidation-reduction precipitation [19,20], solvent extraction [21], and ion exchange processes [22]. Most of these studies were conducted at a higher $\mathrm{Tl}$ concentration using model water [7], which is not consistent with the actual circumstances, i.e., real wastewater, where $\mathrm{Tl}$ concentration therein generally ranges from only a few $\mu \mathrm{g} / \mathrm{L}$ to a few $\mathrm{mg} / \mathrm{L}$ [23], while rarely exceeding $10 \mathrm{mg} / \mathrm{L}$ [24]. Due to mass transfer limitations, the removal efficiency at low concentration may be worse. In this case, further research on the treatment of wastewater with lower $\mathrm{Tl}$ concentration $(<1 \mathrm{mg} / \mathrm{L})$ is essential. In their recent review of $\mathrm{Tl}$ removal processes, Xu et al. [7] highlighted that, until now, only a few studies, where strong oxidants [20,25] or advanced oxidation $[19,26]$ methods were used, reported that the effluent $\mathrm{Tl}$ concentration can meet the $\mathrm{Tl}$ emission standards of industrial wastewater in China $(5 \mu \mathrm{g} / \mathrm{L})$ and of some provincial standards $(2 \mu \mathrm{g} / \mathrm{L})$. Therefore, it is crucial to introduce a cost-effective technology for deep purification of low Tl concentration industrial wastewater to meet the strict emission requirements and reduce the risk of Tl pollution.

Electrocoagulation (EC) is an effective electrochemical wastewater treatment technology [27]. During EC treatment, polymeric metal (usually Fe or Al) hydroxide species were derived in situ, while gas evolved at the cathode. As an easy-to-operate technique, it generates minimal sludge and requires no chemical additives, and it has received considerable attention in recent years as an environmentally friendly option [28,29]. It has been successfully applied to process organic [30-32] and inorganic [33-35] industrial wastewaters. Possessing an ability to thoroughly remove pollutants, EC has also been used in drinking water and surface water treatment [36-38].

In this study, iron electrodes have been used in the EC process. $\mathrm{Fe}^{0}$-electrocoagulation $\left(\mathrm{Fe}^{0}\right.$-EC) products may form in situ monomeric ions, $\mathrm{Fe}(\mathrm{OH})_{\mathrm{n}}(\mathrm{n}=2$ or 3$)$, iron hydroxyl complexes with hydroxide iron ions, and polymeric species (hereafter collectively referred to as iron oxides/hydroxides) which strongly depend on the $\mathrm{pH}$ of the solution [27]. They have a strong affinity for heavy metals, colloidal solids and particles, as well as soluble inorganic pollutants $[27,28]$. The following equations describe the $\mathrm{Fe}^{0}$-EC process.

Anode:

$$
\begin{gathered}
\mathrm{Fe}_{(s)} \rightarrow \mathrm{Fe}_{(a q)}^{2+}+2 e^{-} \\
\mathrm{Fe}_{(a q)}^{2+}+\mathrm{H}_{2} \mathrm{O}+\mathrm{O}_{2(\mathrm{~g} \text { or } \mathrm{DO})} \rightarrow \mathrm{Fe}(\mathrm{OH})_{n}+H_{(a q)}^{+} .
\end{gathered}
$$

Cathode:

$$
2 \mathrm{H}_{2} \mathrm{O}+2 e^{-} \rightarrow \mathrm{H}_{2}+2 \mathrm{OH}_{(a q)}^{-} .
$$

Iron oxides/hydroxides exist in wastewater in the form of a gelatinous suspension, which can remove the pollutants by complexation or electrostatic attraction, followed by coagulation [27]. Metal oxides/hydroxides generated in the EC process have much higher adsorption capacity than the pre-synthetized ones, which guaranteed the removal efficiency [28], especially in the treatment of heavy metals $[33,34,39]$. Although the affinity of $\mathrm{Tl}(\mathrm{I})$ cation to iron oxides/hydroxides is usually 
expected to be weak because it has low $\log \mathrm{K}_{\mathrm{MOH}}$ of $10^{-13.2}$, study [40] shows that $\mathrm{Tl}(\mathrm{I})$ can adsorb well on ferrihydrite in alkaline solutions $(\mathrm{pH}>8)$. Therefore, besides the eight potential feasible technology schemes for different $\mathrm{Tl}$ industry wastewater recommended by $\mathrm{Xu}$ et al. [7], EC may be another feasible solution for low $\mathrm{Tl}$ concentration industrial wastewater treatment. However, there is still insufficient information available on $\mathrm{Tl}$ removal by EC technology. In our initial trial of $\mathrm{Al}^{0}$-EC treatment, the result of $\mathrm{Tl}$ removal was unfortunately not as good as expected. It performs much worse than the $\mathrm{Fe}^{0}$-EC approach (Figure S1). The problem may lie in the fact that $\mathrm{Al}^{0}$-EC can only exert its maximum performance in neutral conditions $[29,41]$, yet the $\mathrm{Tl}$ adsorption performs better at alkaline $\mathrm{pH}$.

Hence, a Fe ${ }^{0}$-EC treatment is proposed in this study for $\mathrm{Tl}$ containing wastewater. The effects of operational parameters, such as initial $\mathrm{pH}$, current density, dissolved oxygen (DO) in wastewater, and initial $\mathrm{Tl}$ concentration, on $\mathrm{Tl}$ removal efficiency from real industrial wastewater were investigated. The flocculent sludge generated under different initial $\mathrm{pH}$ was investigated to reveal the mechanism of $\mathrm{Tl}$ removal. The specific energy consumption under optimized conditions was also calculated with effluent concentration of $5 \mu \mathrm{g} / \mathrm{L}$. The lab-scale batch aeration-forced pump cycle EC reaction system we used is easily converted to continuous mode, which can be easily amplified for a pilot-scale test to evaluate the industrial feasibility of $\mathrm{Tl}$ removal from wastewater with EC technology.

\section{Materials and Methods}

\subsection{Wastewater Sampling}

\subsubsection{Real Industrial Wastewater}

The wastewater was collected from a $\mathrm{Mn}_{3} \mathrm{O}_{4}$ production plant located in Hunan province, China. Its initial $\mathrm{pH}$ value was adjusted in the workshop to c.a. 10 to recover manganese. The wastewater contains a variety of pollutants, among which $\mathrm{Tl}$ is derived from the raw manganese sheets. Because of the fluctuation of pollutant content in this real wastewater, the components therein were detected before each batch of experiments. Five main items were chosen to be measured, and their concentration ranges are shown in Table 1. The concentration range of elements is consistent with long-term industrial monitoring.

Table 1. Concentration range of main elements in the industrial wastewater.

\begin{tabular}{cccccc}
\hline Components & $\mathrm{Tl}(\mu \mathrm{g} / \mathrm{L})$ & $\mathrm{Mn}(\mathrm{mg} / \mathrm{L})$ & $\mathrm{Ca}(\mathrm{mg} / \mathrm{L})$ & $\mathrm{Mg}(\mathrm{mg} / \mathrm{L})$ & $\mathrm{Cl}^{-}(\mathrm{g} / \mathrm{L})$ \\
\hline Concentration range & $66-165$ & $0.1-0.3$ & $1-5$ & $30-50$ & $2.0-2.2$ \\
\hline
\end{tabular}

The initial $\mathrm{Tl}$ concentration varied according to different manganese raw materials. Chloride salt was usually used as a supporting electrolyte to increase the electrical conductivity of wastewater and relieve electrode passivation in EC treatment [33,42]. There is no need to add supporting electrolytes additionally since the chloride ions therein amount to $2.0 \mathrm{~g} / \mathrm{L}$.

\subsubsection{Artificial Wastewater}

To study the forms of $\mathrm{Tl}$ in flocculent sludges, it is necessary to ensure that $\mathrm{Tl}$ content therein is larger than the detectable lower limit of the analyzing apparatus. For this purpose, $\mathrm{Tl}$ content was intentionally adjusted. The artificial samples with high $\mathrm{Tl}$ concentration were prepared by dissolving the corresponding amount of $\mathrm{TINO}_{3}(99.9 \%$, Sigma-Aldrich, USA) in the real wastewater to obtain suitable thallium-containing sludge.

\subsection{EC Operation Procedure}

The experiments were carried out at room temperature with an aeration-forced pump cycling reaction system in batch mode. Connected by pipelines and valves, the EC reactor, direct current (DC) 
power supply, iron electrode plates, circulating pump, and rotameter were assembled to construct this reaction system. The plexiglass reactor consisted of a reaction tank and an overflow tank with a total valid volume of $2.7 \mathrm{~L}$. The reaction tank had dimensions of $101 \mathrm{~mm} \times 150 \mathrm{~mm} \times 100 \mathrm{~mm}$. Vertical grooves with a depth of $2.5 \mathrm{~mm}$ and a groove space of $10 \mathrm{~mm}$ were carved on the side wall of the reaction tank, which stopped at $30 \mathrm{~mm}$ above the reaction tank bottom, for placing electrode plates. The iron (carbon steel, Q325) plates with dimensions of $103 \mathrm{~mm} \times 140 \mathrm{~mm} \times 2 \mathrm{~mm}$ (wide $\times$ height $\times$ thick) were used as sacrificial electrodes. Two electrodes were positioned vertically in the groove of the reaction tank with a minimum and maximum distance of $10 \mathrm{~mm}$ and $60 \mathrm{~mm}$, respectively. Figure 1 shows the schematic diagram of the EC setup. The effective surface area immersed in wastewater of one single electrode was $121.2 \mathrm{~cm}^{2}$. The top ends of plates, located $20 \mathrm{~mm}$ above the wastewater surface, were connected to a DC power supply (Zhaoxin RXN-3010D, 0-10 A, 0-30 V, China) by an alligator clip. A pump (Mingling ML-200, 4 L/min, China) was used to provide cycle flow for the reaction system. An air pipe was installed at the inlet of the pump for inhaling air. The inhaled air volume was regulated by a valve and measured by a rotor flowmeter. A pH meter (Thermo, Orion star A211, USA) was used to measure the initial $\mathrm{pH}$ of the wastewater. The $\mathrm{pH}$ value was adjusted using diluted $\mathrm{HCl}$ or $\mathrm{NaOH}$. The solution conductivity and $\mathrm{DO}$ concentration were measured by using a conductivity meter (REX, DDS-307, China) and RDO/DO meter (Thermo, Orion star A223, USA), respectively. The instant $\mathrm{pH}$ value, solution conductivity, and $\mathrm{DO}$ of the wastewater were continuously monitored during each experiment.

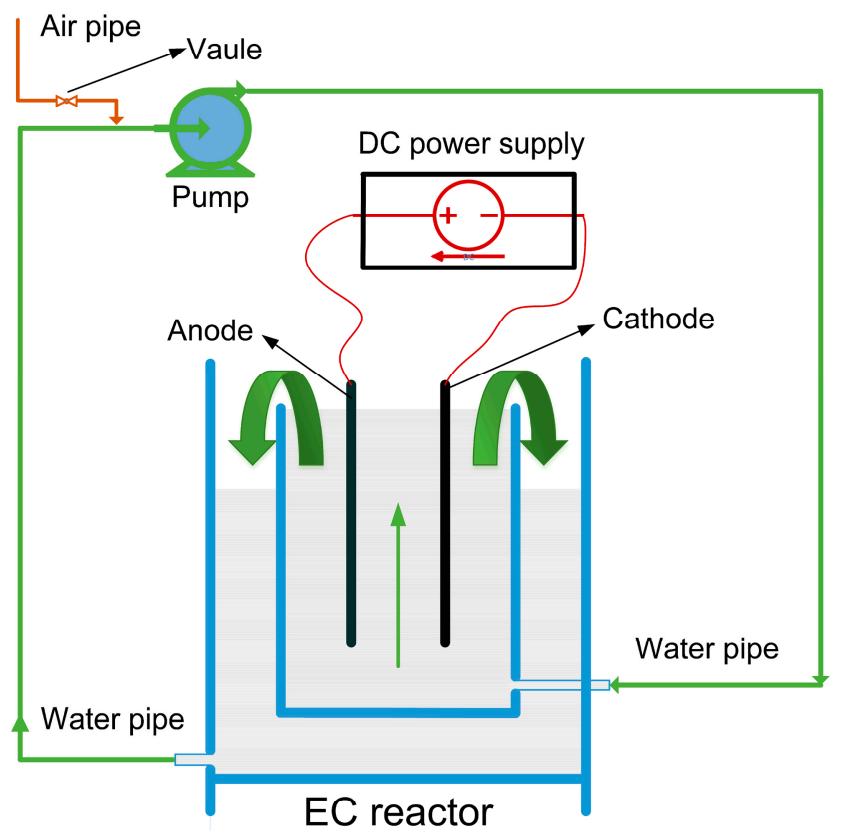

Figure 1. Schematic diagram of the electrocoagulation (EC) setup.

For every single experiment, the iron plates were pre-polished with abrasive paper (600 grit), and then cleaned quickly with diluted $\mathrm{HCl}$ (5 wt.\%) and rinsed with water to eliminate the attachments on the surface. After each experiment, the plates were cleaned with water and stored in diluted $\mathrm{HCl}$ (1 wt.\%). Water samples with a volume of $20 \mathrm{~mL}$ were taken at $2 \mathrm{~min}$ intervals during the pre-determined time, then filtrated using a microfiltration membrane (Xinya, mixed fiber film, $0.45 \mu \mathrm{m}$, China). All experiments were triplicated, and the results were given as average. For the initial stage of electrolysis, the standard errors were no more than $5 \%$, and this will be less than $1 \%$ with the prolongation of time. Filtrate was collected and analyzed. Flocculent sludge obtained in the experiment was separated and collected by filtration, dried in a vacuum drying oven $\left(50{ }^{\circ} \mathrm{C}\right.$, vacuum degrees of $-80 \mathrm{kPa}$ ) for $12 \mathrm{~h}$ before being sealed and stored in a refrigerator for further analyses. 
The Tl percent removal efficiency was calculated by Equation (4):

$$
\eta(\%)=\frac{C_{0}-C}{C_{0}} \times 100
$$

where $C_{0}$ and $C$ are the concentrations of $\mathrm{Tl}$ in the original wastewater sample and in the EC processed one, respectively.

The energy consumption of the overall EC treatment was calculated using Equation (5):

$$
E_{\text {cons }}=\frac{U \times I \times t}{V}
$$

where $E_{\text {cons }}$ is the energy consumption $\left(\mathrm{kWh} / \mathrm{m}^{3}\right), U$ is the operating voltage $(\mathrm{V}), I$ is the matching current (A), $t$ is the EC operating time (h), $V$ is the treated wastewater volume (L).

According to Faraday's law, the theoretical dissolved mass of sacrificial anodes was calculated with the following Equation (6):

$$
m=\frac{I \times t \times M}{z \times F},
$$

where $m$ is the mass (g) of the dissolved anode material, $I$ is the current density (A), $t$ is the electrolysis operating time (s), $M$ is the molecular weight of the anode material $(\mathrm{g} / \mathrm{mol}), z$ is the number of electrons involved in the EC reaction, and $F$ is Faraday's constant $(96,485.33 \mathrm{C} / \mathrm{mol})$.

In order to investigate the absorption capacity of different $\mathrm{FeOOH}$ obtained by the $\mathrm{Fe}^{0}$-EC process, the as-prepared $\mathrm{FeOOH}$ was added into $50 \mathrm{~mL}$ of centrifuge tubes with $30 \mathrm{~mL} \mathrm{Tl}(\mathrm{I})$-containing wastewater. The suspension was shaken at $100 \mathrm{rpm}$ for $4 \mathrm{~h}$ in a shaker at room temperature. Then it was filtered through a microfiltration membrane (Xinya, mixed fiber film, $0.45 \mu \mathrm{m}$, China) and the $\mathrm{Tl}$ concentration in the filtrates was determined.

\subsection{Characterization}

$\mathrm{Tl}$ concentration in the water sample was measured by inductively coupled plasma mass spectrometry (ICP-MS), using iCAP RQ (Thermo, Waltham, USA) with a lower detection limit of $0.01 \mu \mathrm{g} / \mathrm{L}$. Each group of contrast data was sampled at the same batch in order to reduce the impact of instrument errors. Concentrations of other metals or high Tl content $(>1.0 \mathrm{mg} / \mathrm{L})$ were determined by atomic absorption spectrometry (AAS) with spectrometer WYS2200 (Wayeal Co. Ltd., Hefei, China). The phase composition of flocculent sludges was determined by X-ray diffraction analysis (XRD) using D8 advance (Bruker, Berlin, Germany) with a $\mathrm{Cu} \mathrm{K} \alpha$ X-ray source. To investigate the morphology of the flocculent sludges, scanning electron microscopy (SEM) observation was conducted using JSM-7900F (JEOL, Akishima, Japan). X-ray photoelectron spectroscopy (XPS) study was conducted using ESCALAB 250Xi (Thermo, Waltham, USA) with a monochromatized Al $K_{\alpha}$ source operated at $150 \mathrm{~W}$. Fourier transform infrared spectroscopy (FT-IR) was adopted to characterize functional groups on flocculent sludges using Nexus 670 (Thermo Nicolet, Waltham, USA) over a wavenumber range from 400 to $4000 \mathrm{~cm}^{-1}$. The specific surface area, average pore size and pore volume were measured by nitrogen adsorption using density functional theory (DFT) method with surface area and pore size analyzer Quadasorb SI-3 (Quantachrome Instruments, Boynton Beach, USA). The precise content of $\mathrm{Tl}$, total $\mathrm{Fe}(\mathrm{TFe})$, and the proportion of different iron valence states in the flocculent sludge were measured by chemical analysis method.

\section{Results and Discussion}

\subsection{Effect of Initial $p H$}

The $\mathrm{pH}$ value of the wastewater is a key factor affecting EC treatment efficiency. Solution conductivity, zeta potential, and electrode dissolution [29,43], especially the metal oxides/hydroxides species generated therein and the coagulation mechanism of EC treatment [44,45], are all influenced by 
$\mathrm{pH}$ value. Since the $\mathrm{pH}$ value varies during EC processing [46,47], the initial $\mathrm{pH}$ of the solution was used to study the effect of $\mathrm{pH}$ on EC performance.

It is noteworthy that, like the artificial samples configured with $\mathrm{TlNO}_{3}$ and $\mathrm{NaCl}$, simply adjusting the $\mathrm{pH}$ value has little effect on $\mathrm{Tl}$ content in the real wastewater. It can be concluded that there is no co-precipitation occurring in the $\mathrm{Fe}^{0}$-EC treatment for $\mathrm{Tl}$ removal from the real wastewater. This testifies that $\mathrm{Tl}(\mathrm{I})$ is the dominate $\mathrm{Tl}$ component, so the $\mathrm{Tl}$ element in the target water is hereafter referred as $\mathrm{Tl}(\mathrm{I})$. Meanwhile, the microgram level $\mathrm{Tl}(\mathrm{I})$ content in the wastewater at room temperature is not a solubility-controlling phase owing to the high solubility of $\mathrm{TlCl}[48,49]$.

Studies have shown that there is a strong correlation between EC treatment effect and the initial $\mathrm{pH}$, which is variable according to different pollutants [28,29]. The EC removal of Tl(I) from wastewater, especially that with low $\mathrm{Tl}(\mathrm{I})$ concentration, has been rarely studied. Besides, the $\mathrm{Tl}(\mathrm{I})$ sorption is appreciable at alkaline $\mathrm{pH}$ [40]. To evaluate EC treatment effects, a series of experiments were performed to treat low $\mathrm{Tl}(\mathrm{I})$ samples with a comparatively broader initial $\mathrm{pH}$ range of 7-12. The initial $\mathrm{pH}$ was adjusted by adding diluted $\mathrm{HCl}$ or $\mathrm{NaOH}$. As can be seen from Figure 2, $\mathrm{Tl}(\mathrm{I})$ removal rates are $19.1 \%, 27.7 \%$, and $70.9 \%$ at $\mathrm{pH} 7,8$, and 9, respectively, with applied current density $16.7 \mathrm{~mA} / \mathrm{cm}^{2}$, after 20 min $\mathrm{Fe}^{0}$-EC treatment. Meanwhile, the Tl(I) removal efficiency increased significantly when the $\mathrm{pH}$ value increased from 9 to 10 or more. The best removal effect was achieved when the initial $\mathrm{pH}$ was 11 , to be precise, after the water with feed concentration of $141 \mu \mathrm{g} / \mathrm{L}$ was processed by the EC treatment for 6 and $18 \mathrm{~min}$ at $\mathrm{pH} \mathrm{11,} \mathrm{the} \mathrm{residual} \mathrm{Tl}(\mathrm{I})$ concentration was reduced respectively to be less than $5 \mu \mathrm{g} / \mathrm{L}$ and $2 \mu \mathrm{g} / \mathrm{L}$. These results meet the national wastewater emission standards and some strictest provincial standards in China, respectively. They are also comparable with the maximum permissible $\mathrm{Tl}$ concentration for drinking water suggested by USEPA [50].
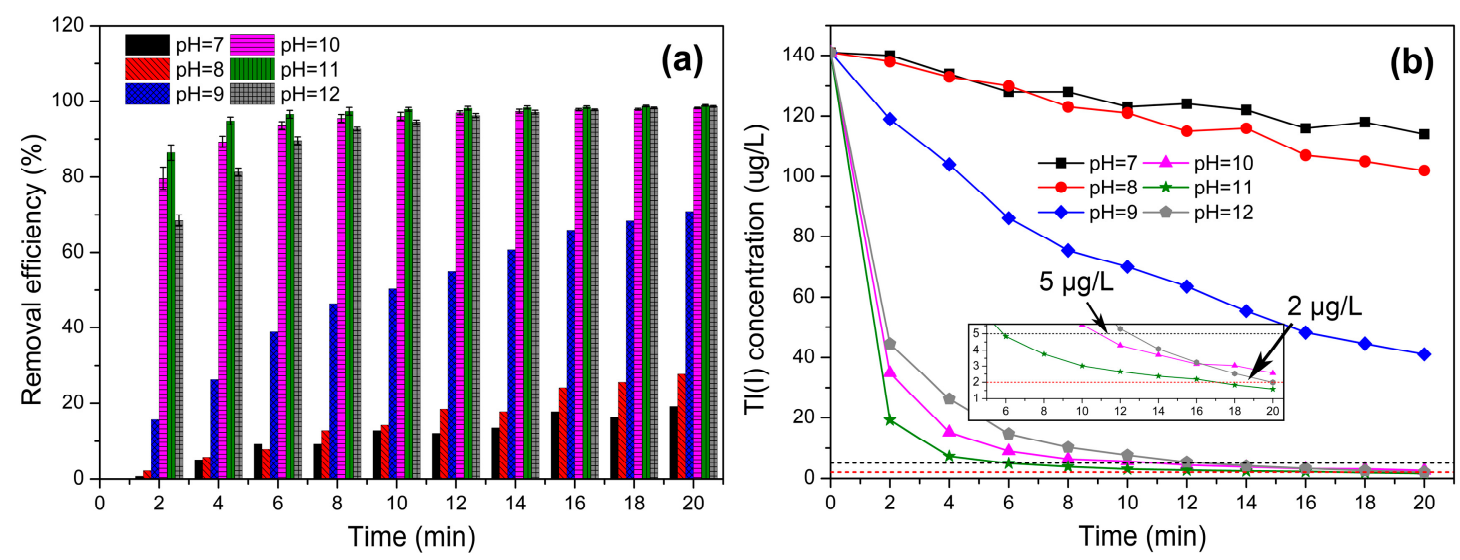

Figure 2. Effect of initial $\mathrm{pH}$ on (a) removal efficiency, (b) concentration of $\mathrm{Tl}(\mathrm{I})$ within a $20 \mathrm{~min} \mathrm{EC}$ treatment under an applied current density of $16.7 \mathrm{~mA} / \mathrm{cm}^{2}$ with aeration of $0.2 \mathrm{~L} / \mathrm{min}$, using Fe-Fe electrodes at a distance of $2 \mathrm{~cm} . \mathrm{C}_{0}=141 \mu \mathrm{g} / \mathrm{L}$.

The effect of solution $\mathrm{pH}$ on ion adsorption can be achieved by changing the surface charge properties of the adsorbent. The Tl(I) removal capacity of EC treatment increased along with the initial $\mathrm{pH}$, which may be due to the changes of $\mathrm{pH}$-dependent electrostatic force existing between the iron oxides/hydroxides and $\mathrm{Tl}$ species. The point of zero charge (PZC) of synthetic Fe-oxides usually ranges between $\mathrm{pH} 7$ and 9 [51]. For instance, the $\mathrm{PZC}$ of $\delta$-FeOOH is measured as 8.4 [52]. In the solution with a $\mathrm{pH}$ value higher than the $\mathrm{PZC}$, the adsorption capacity of iron oxides/hydroxides increases as it can favor the electrostatic attraction between them and $\mathrm{Tl}(\mathrm{I})$ ions. This is consistent with the adsorption behavior of $\mathrm{Tl}(\mathrm{I})$ on ferrihydrite which is only appreciable at alkaline $\mathrm{pH}$ [40]. Since $\mathrm{Tl}(\mathrm{I})$ is converted to $\mathrm{TlOH}_{(\mathrm{aq})}$ at high $\mathrm{pH}(11.7)$, as suggested by Lin and Nriagu [25], an excessive $\mathrm{pH}$, i.e., intensified converting, will reduce the adsorption efficiency of $\mathrm{Tl}$ species.

It is noteworthy that when the initial $\mathrm{pH}$ value exceeded 12 , less flocs formed and $\mathrm{Tl}(\mathrm{I})$ removal efficiency declined. The main reason for flocs' reduction may relate to the anodic passivation at higher 
$\mathrm{pH}$, which inhibits the dissolution of the sacrificial anode [53]. The superposition factors for the flocs reduction can be attributed to the lower corrosion rate of iron, as can be seen from its corrosion rate-pH chart [30] and the formation of soluble $\mathrm{Fe}(\mathrm{OH})_{4}{ }^{-}$in alkaline $\mathrm{pH}$ [54]. In addition, when the initial $\mathrm{pH}$ value increased from 11 to 12 , the specific surface area of the flocculent sludge decreased by $7.83 \%$ and the pore volume decreased by $17.6 \%$, while the average pore diameter decreased slightly (Table S2). This change may lead to the decrease of active adsorption sites on the flocculent sludge and then the decrease of $\mathrm{Tl}(\mathrm{I})$ removal efficiency.

After treatment at different initial $\mathrm{pH}$, flocculent sludges share a similar composition, but varied crystal structure. XRD patterns, FT-IR spectra, and SEM images of flocculent sludges generated under different initial pH are shown in Figure 3. As shown in Figure 3a, the main phase of the sludges generated under aeration is iron oxyhydroxide, which is in the form of lepidocrocite $(\gamma$-FeOOH) at initial $\mathrm{pH} 7$ and 8, feroxyhyte with less ordered crystallinity ( $\left.\delta^{\prime}-\mathrm{FeOOH}\right)$ [55] at an initial $\mathrm{pH}$ above 10, or a mixture of them at an initial $\mathrm{pH}$ of 9 . Both $\mathrm{FeOOH}$ forms were supposed to be obtained under different reaction conditions in $\mathrm{Fe}^{2+}$-containing solution [56], which is consistent with the conclusion that $\mathrm{Fe}^{2+}$ forms at the anode in the $\mathrm{Fe}^{0}$-EC process [54,57]. The inter-conversions between the various monomeric iron ions, iron oxides/hydroxides, and polymeric hydroxyl complexes are possible and often occur readily [56]. Both high $\mathrm{pH}$ and high $\mathrm{DO}$ concentration can enhance the oxidation rate of $\mathrm{Fe}^{2+}$ to form feroxyhyte, while slow oxidation rate and neutral $\mathrm{pH}$ benefit the formation of lepidocrocite [55]. Further research shows that oxidation rate was greatly affected by DO concentration and is a key factor for formation of feroxyhyte. Detailed discussion on DO can be found in Section 3.2.

XRD patterns show that, with the increase of $\mathrm{pH}$, the diffraction peak broadens while it declines in intensity (Figure 3a). This indicates that the flocs generated at high $\mathrm{pH}$ possessed less-ordered crystalline characteristics, which are possibly more favorable in offering reactive sites compared to the low $\mathrm{pH}$ ones. When the $\mathrm{pH}$ value exceeds 9, the characteristic peaks of lepidocrocite disappeared and feroxyhyte became the main phase. It can be clearly observed on the FT-IR spectra of the flocculent sludges (Figure $3 b$ ) that obvious differences exist in the structures and functional groups on flocculent sludges obtained at different initial $\mathrm{pH}$ values. The spectra obtained are similar to those reported in the literature $[55,56,58]$. Adsorption peaks located at 3383.28, 1624.58, 1067.29, and $680.37 \mathrm{~cm}^{-1}$ on the spectra of flocculent sludges obtained at high $\mathrm{pH}$ correspond to the characteristic bands of feroxyhyte [55]. Meanwhile, the characteristic bands on the spectra of flocculent sludges obtained at low $\mathrm{pH}$ show that they are of lepidocrocite phase [58].

The morphology of flocculent sludges varied along with the initial $\mathrm{pH}$ value. As demonstrated in Figure $3 \mathrm{c}$, sludges generated at a low $\mathrm{pH}$ value $(\mathrm{pH}=7,8)$ exhibited mainly honeycomb-like platelet structure with curls at the edge or stacked small platelets. Nanosheets c.a. 200-300 nm in length and $20 \mathrm{~nm}$ in thickness form a large flower-like structure by staggered accumulation create. The porosity of the samples increases as more pores and channels appeared. As the $\mathrm{pH}$ increases, the sludge is more likely to form a sheet stacking structure, which was also described by Chukhrov et al. [55]. Until the $\mathrm{pH}$ exceeds 9 , instead of forming a honeycomb-like structure, the sludge looks like aggregates of smaller platelet nanosheets with a size of about 100-200 nm and thickness of 10-20 nm.

The effects of solution $\mathrm{pH}$ on the adsorption properties of the two FeOOH samples, which were obtained by electrolysis of salt water at initial $\mathrm{pH}$ of 7 and 11, were compared. According to the number of flocs produced by EC for $20 \mathrm{~min}, 13.2 \mathrm{mg} \mathrm{FeOOH}$ powder was added into $30 \mathrm{~mL}$ real wastewater. As illustrated in Figure S3, for the low $\mathrm{Tl}(\mathrm{I})$ concentration wastewater, feroxyhyte has better Tl(I) removal efficiency than that of lepidocrocite over the $\mathrm{pH}$ range of 7-11. Possessing higher specific surface area than lepidocrocite (Table S2), feroxyhyte can provide more active adsorption sites for $\mathrm{Tl}(\mathrm{I})$ and contribute to the increase of $\mathrm{Tl}(\mathrm{I})$ removal efficiency. 

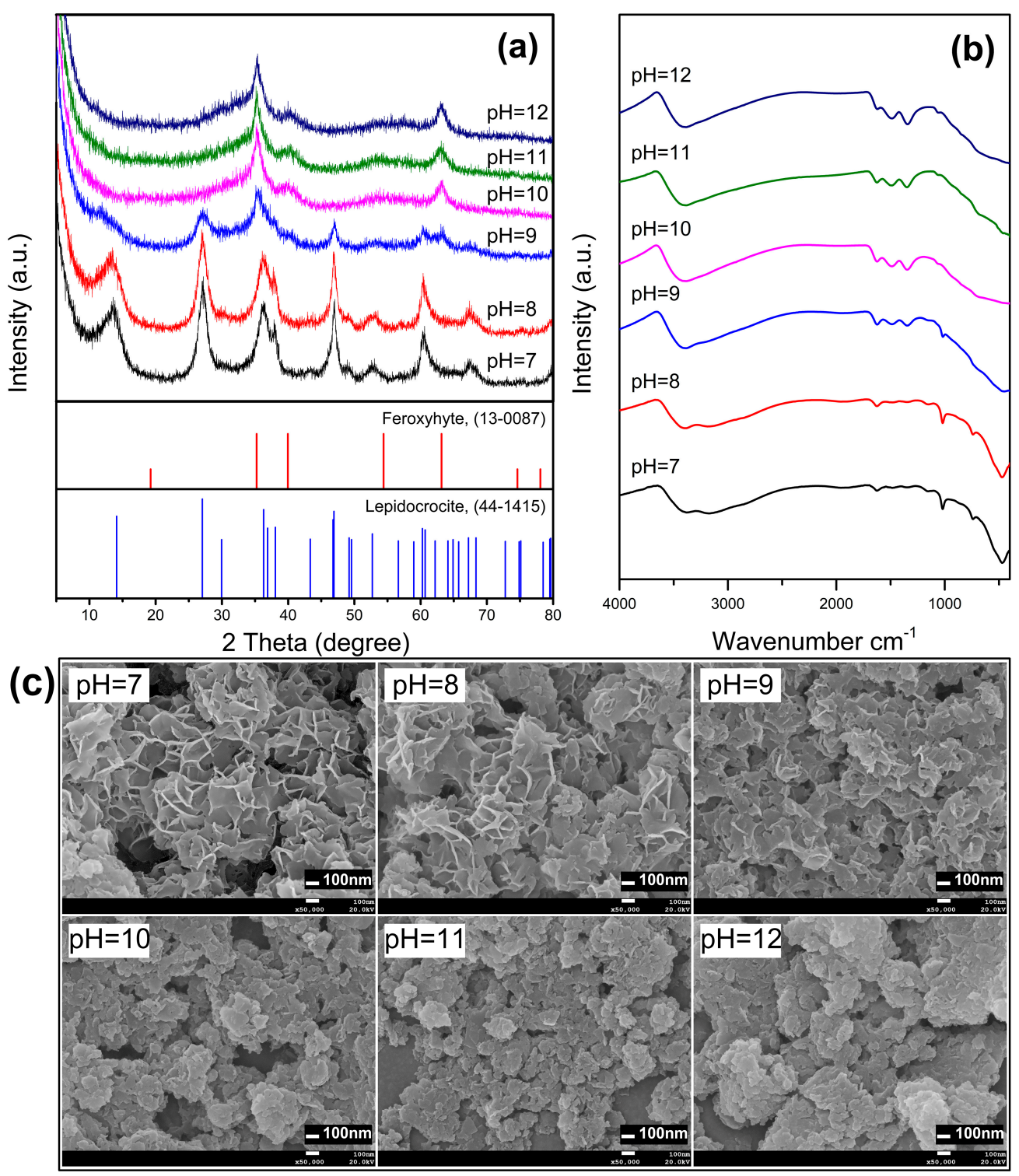

Figure 3. Effect of initial $\mathrm{pH}$ on flocculent sludge (a) crystal structure; (b) surface groups; (c) micromorphology, from a $20 \mathrm{~min}$ EC treatment applying a current density of $16.7 \mathrm{~mA} / \mathrm{cm}^{2}$ with aeration of $0.2 \mathrm{~L} / \mathrm{min}$, using $\mathrm{Fe}-\mathrm{Fe}$ electrodes at a distance of $2 \mathrm{~cm}$.

The variation of $\mathrm{pH}$ during the EC process is mainly a combined effect of $\mathrm{OH}^{-}$generation at the cathode (Equation (3)) and the hydrolysis reaction (Equation (2)) of equivalent amount of $\mathrm{Fe}^{2+}$ formed at the anode. Furthermore, some $\mathrm{Fe}(\mathrm{OH})_{4}{ }^{-}$is likely to form at alkaline $\mathrm{pH}$ and result in consumption of $\mathrm{OH}^{-}$, which can also explain the decrease of $\mathrm{pH}$ [54]. Generally, the effluent $\mathrm{pH}$ would increase for acidic influent, but can decrease for alkaline influent [29,47]. As shown in this study, after 20 min EC treatment with aeration, the effluent $\mathrm{pH}$ value from the influent $\mathrm{pH}$ of 9, 10, 11, and 12 decreased respectively to $8.68,9.46,10.43$, and 11.76 , while the effluent $\mathrm{pH}$ from influent $\mathrm{pH}$ of 7 increased to 7.85 , and there was no obvious change for the influent $\mathrm{pH}$ of 8 at current density of $16.7 \mathrm{~mA} / \mathrm{cm}^{2}$. It is noteworthy that the decrease of effluent $\mathrm{pH}$ has no visible negative effect on $\mathrm{Tl}(\mathrm{I})$ removal efficiency, because feroxyhyte will form continuously in a solution with $\mathrm{pH}$ above 10 under aeration. As illustrated in Figure 2a, the removal rate of $\mathrm{Tl}(\mathrm{I})$ increases steadily and slightly after the maximum removal efficiency stage. 
The influence of coexisting ions such as $\mathrm{Mg}$ (Table 1) on $\mathrm{Tl}(\mathrm{I})$ removal efficiency, especially in wastewater with high $\mathrm{pH}$ value, is also neglectable. According to the removal efficiency data, in the presence of $\mathrm{Mg}$ under different initial $\mathrm{pH}$ (Figure S2), coprecipitation of $\mathrm{Mg}$ occurs at high $\mathrm{pH}$ and its competition with $\mathrm{Tl}(\mathrm{I})$ for active adsorption sites on the surface of iron oxides/hydroxides, may also be another reason causing the decrease of $\mathrm{Tl}(\mathrm{I})$ removal efficiency at $\mathrm{pH}=12$.

\subsection{Effect of DO in Wastewater}

Studies on the valence state of iron ions generated from the sacrificial anode during the EC process indicated that ferrous was the main form of anodic dissolution [54,57]. Generally, ferrous constituents are more soluble than ferric constituents [59], only when insoluble ferric oxide flocculate is formed by ferrous oxidation can pollutants in water be effectively removed. The spontaneous chemical oxidation of ferrous to ferric in solution is a complex process [60]. The rate and degree of oxidation depends on parameters such as $\mathrm{pH}, \mathrm{DO}$, solution composition and temperature, which affect the structure of flocculent sludge and the pollutant removal efficiency. Study showed that there is a second order relationship between the oxidation rate and the hydroxyl ion concentration at a $\mathrm{pH}$ range of 6.0-7.5 [59], which means that the reaction rate can be increased by more than 100-fold with an increase of one $\mathrm{pH}$ unit. Nevertheless, when $\mathrm{pH}$ exceeds 8.1, the rate appeared to be independent of $\mathrm{pH}$ value [60]. Furthermore, the oxidation of $\mathrm{Fe}^{2+}$ to $\mathrm{Fe}^{3+}$ was very fast with the presence of trace DO, especially in alkaline solutions, the rate of $\mathrm{Fe}^{2+}$ oxidation by $\mathrm{DO}$ can be significantly promoted [54]. This indicates that $\mathrm{DO}$, rather than the chemical reaction, determines the oxidation rate in alkaline environments. DO concentration in an alkaline solution is a major determinant of the rate and extent of ferrous oxidation, which has an important influence on the crystal structure of iron oxides/hydroxides [56].

As illustrated in Figure $4 \mathrm{a}$, the DO concentration, near-saturated $(7.5-8 \mathrm{mg} / \mathrm{L})$ at room temperature in $2.7 \mathrm{~L}$ wastewater, can be maintained at around $4.7 \mathrm{mg} / \mathrm{L}$ based on the DO consumption rate during the EC process with forced aeration at a current density of $16.67 \mathrm{~mA} / \mathrm{cm}^{2}$ and a $\mathrm{pH}$ of 11 . By contrast, the residual DO was less than $100 \mu \mathrm{g} / \mathrm{L}$ in around $8 \mathrm{~min}$ of electrolysis without aeration under the same open atmospheric condition.

As shown in Figure $4 b$, the $\mathrm{Tl}(\mathrm{I})$ removal efficiency under non-aerated conditions was almost the same as that of aerated conditions before the DO was depleted, showing that the DO plays a role in promoting the hydrolysis reaction (Equation (2)). Along with the depletion of initial DO, the $\mathrm{Tl}(\mathrm{I})$ removal efficiency starts to decline after it had reached its summit. It may be that the lack of DO in wastewater inhibits the oxidation of ferrous, thereby slowing down or even stopping the deprotonation process according to Equation (2) [33], and resulting in the formation of green rust, which contains lot of ferrous ions (Figure $4 \mathrm{~b}$ ). Feroxyhyte formed in the first $8 \mathrm{~min}$ may partially transform to a new phase by the catalytic dissolution action of ferrous ions and reprecipitation process [61,62], meanwhile, some captured $\mathrm{Tl}(\mathrm{I})$ may re-release into the wastewater in the phase transition process.

DO concentration also has an important influence on the crystal structure of iron oxides/hydroxides, which then affects the removal efficiency of $\mathrm{Tl}(\mathrm{I})$ in wastewater. XRD patterns of flocculent sludges generated at different aerated conditions are shown in Figure 4c. It was found that no green rust formed under aerated conditions, while without aeration, the formation of green rust begins to increase with DO consumption (Figure 4a). This indicated that ferrous ions oxidized rapidly under forced aeration. Very rapid oxidation is essential for feroxyhyte formation. Unlike the direct formation of feroxyhyte by rapid oxidation, green rust prefers to be transformed into the final product by dissolution and recrystallization, then magnetite is formed at a lower oxidation rate under alkaline conditions $[56,63]$. 

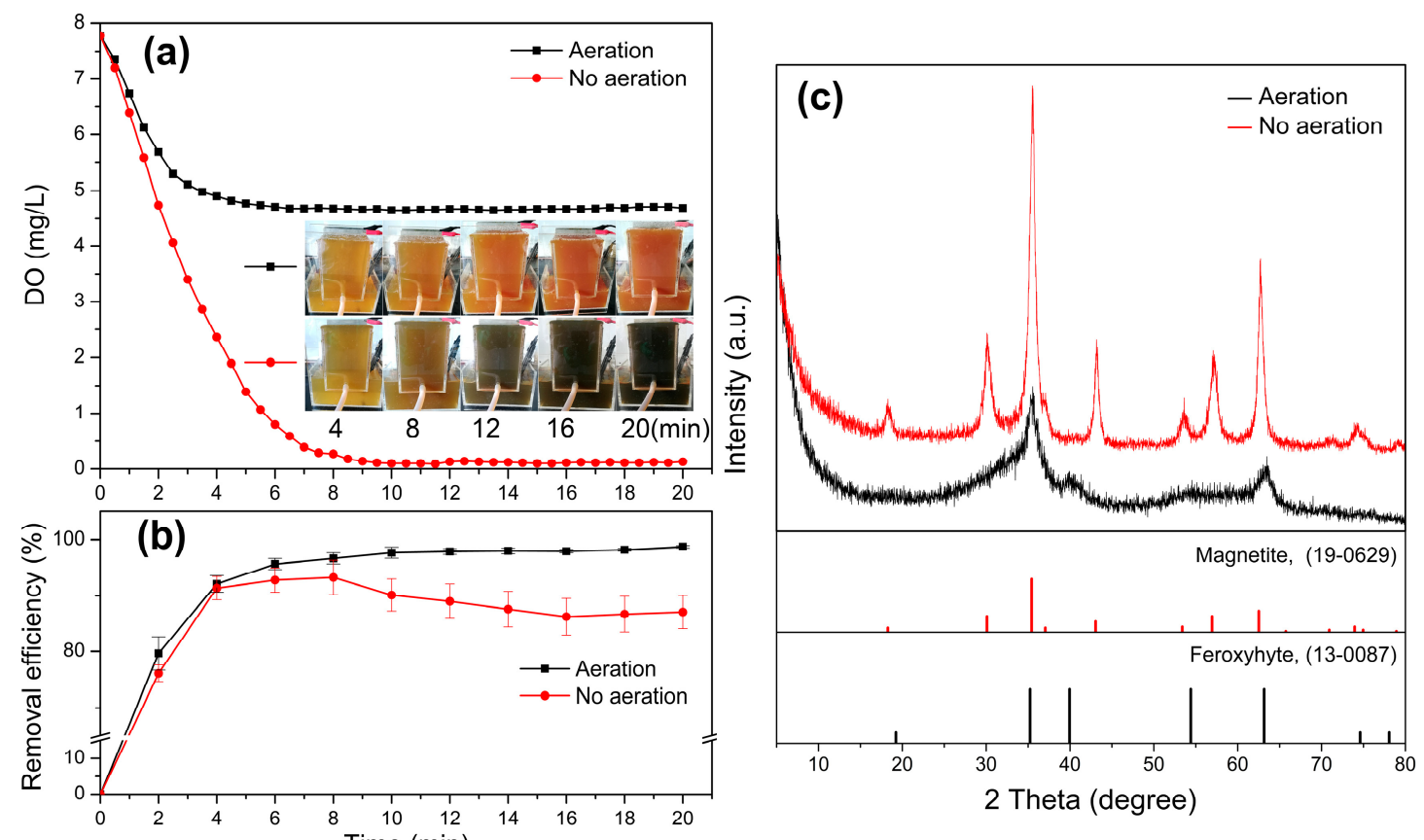

Figure 4. Effect of aeration of $0.2 \mathrm{~L} / \mathrm{min}$ and no aeration on (a) $\mathrm{Tl}(\mathrm{I})$ removal efficiency, (b) dissolved oxygen (DO) concentration, and (c) X-ray patterns of flocculent sludge within a 20 min EC treatment under an applied current density of $16.7 \mathrm{~mA} / \mathrm{cm}^{2}$ at initial $\mathrm{pH}$ of $11 \pm 0.1$, using Fe-Fe electrodes at a distance of $2 \mathrm{~cm} . \mathrm{C}_{0}=109 \mu \mathrm{g} / \mathrm{L}$.

It is feasible to maintain the $\mathrm{DO}$ concentration by forced aeration. The DO concentration plays an important role in $\mathrm{Tl}(\mathrm{I})$ removal as it affects the distribution of different valence iron in wastewater and the crystal structure of flocs. Feroxyhyte generated by aeration-forced $\mathrm{Fe}^{0}$-EC is a key factor for the rapid and thorough removal of $\mathrm{Tl}(\mathrm{I})$. Furthermore, an additional benefit of aeration is that the bubbles help to alleviate concentration polarization and flocculation separation. It is worth noting that it is not an essential condition to apply the aeration law in this work to all EC processes. For processes relying on the reducibility of ferrous, it is unnecessary to aerate while electrolyzing [33,42]. As an important parameter of the EC process, regulation by aeration can be adapted to the removal mechanism of different pollutants.

Amid the EC treatment of the wastewater with an initial $\mathrm{pH}$ of 11 under non-aerated conditions, the effluent $\mathrm{pH}$ decreased slightly to 10.94 after $8 \mathrm{~min}$, namely, before the exhaustion of DO. Yet the effluent $\mathrm{pH}$ increased to 11.28 after $20 \mathrm{~min}$ of $\mathrm{EC}$ treatment. The degree of hydrolysis of ferrous bivalent decreases due to the decrease of DO concentration in solution, and the deprotonation (depending on Equation (2)) process almost stops when DO is depleted [33]. That means the cathodic reaction plays a leading role resulting the increase of effluent $\mathrm{pH}$ even in alkaline conditions. It indicates that the EC process will lose its $\mathrm{pH}$ buffering effect when the DO in wastewater is depleted.

\subsection{Effect of Applied Current Density}

Current density has been considered an important factor affecting EC performance [29]. For electrodes with equal area, the amount of ferrous released from iron electrodes, according to Faraday's law, is generally proportional to the current density. The number of flocs and the bubbles derived from the cathode augment with increasing current density $[64,65]$. The current density determines the coagulant dosage rate and the bubble production rate, which affects the mass transfer inside the reactor [66].

At an initial solution conductivity of $7.9 \mathrm{mS} \cdot \mathrm{cm}^{-1}$, current densities of $8.3,16.7,25$, and $33.3 \mathrm{~mA} / \mathrm{cm}^{2}$ were applied to EC processes with applied voltages of 3.6, 5.5, 7.8, and $9.9 \mathrm{~V}$, respectively. Figure 5 
shows the effect of current densities on the removal efficiencies and residual $\mathrm{Tl}(\mathrm{I})$ concentrations. It indicates that the removal rate climbs with the increase of current density, even though the increase is smaller stepwise. After 4 min EC treatment, the $\mathrm{Tl}(\mathrm{I})$ removal rates are $85.57 \%, 94.57 \%, 96.79 \%$, and $98.31 \%$ at the current densities of $8.3,16.7,25$, and $33.3 \mathrm{~mA} / \mathrm{cm}^{2}$, respectively. The cumulative removal efficiencies of $\mathrm{Tl}(\mathrm{I})$ were continuing to increase as the electrolysis continued, as illustrated in Figure $5 \mathrm{a}$. For the initial $\mathrm{Tl}(\mathrm{I})$ concentration of $115 \mu \mathrm{g} / \mathrm{L}$, as shown in Figure 5b, the residual concentrations were less than $5 \mu \mathrm{g} / \mathrm{L}$ after operating for 12, 6, 4, and $4 \mathrm{~min}$ at the current densities of 8.3, 16.7, 25, and $33.3 \mathrm{~mA} / \mathrm{cm}^{2}$, respectively. Longer operation time is needed to meet some Chinese provincial emission standards for industrial wastewater $(2 \mu \mathrm{g} / \mathrm{L})$. The residual concentrations were less than $2 \mu \mathrm{g} / \mathrm{L}$ after operation for 12, 8 , and $6 \mathrm{~min}$ at the current densities of $16.7,25$, and $33.3 \mathrm{~mA} / \mathrm{cm}^{2}$, respectively, based on the initial Tl(I) concentration of $115 \mu \mathrm{g} / \mathrm{L}$.

With a capacity for deep purification, EC treatment has been used for purification of surface water and drinking water $[36,45,67]$. This capacity displays in Tl(I) removal too, as after EC processing, the residual $\mathrm{Tl}(\mathrm{I})$ concentration can be reduced to $0.5 \mu \mathrm{g} / \mathrm{L}$, or even lower with a prolonged electrolysis time.
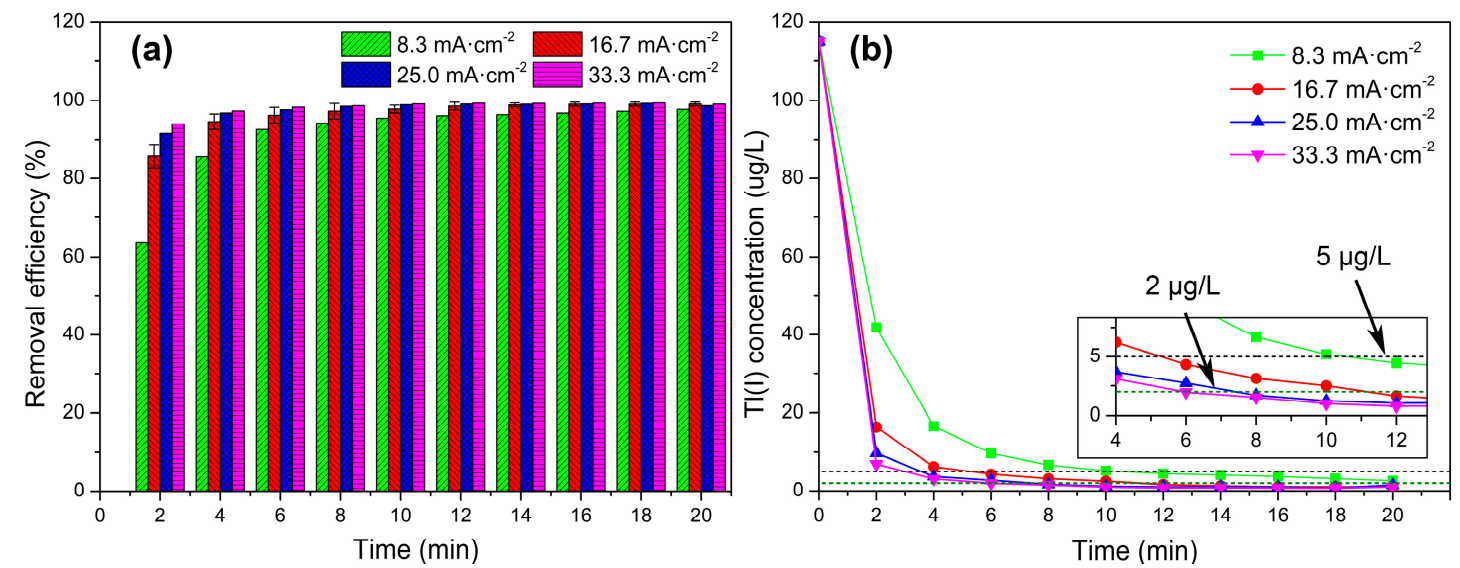

Figure 5. Effect of current density on (a) removal efficiency, (b) concentration of Tl(I) within 20 min EC treatment under initial $\mathrm{pH}$ of $11 \pm 0.1$, using Fe-Fe electrodes at a distance of $2 \mathrm{~cm}$. Aeration of $0.2 \mathrm{~L} / \mathrm{min} . \mathrm{C}_{0}=115 \mu \mathrm{g} / \mathrm{L}$.

Sodium chloride can increase solution conductivity while minimize the energy consumption $[32,33]$. Wastewater samples with $0.5,1.0,1.5$, and $2.0 \mathrm{~g} / \mathrm{L} \mathrm{Cl}^{-}$as the supporting electrolyte were treated at current density of $16.7 \mathrm{~mA} / \mathrm{cm}^{2}$. The results (Figure S4) show that, the $\mathrm{Tl}(\mathrm{I})$ removal efficiency increases with the increase of $\mathrm{Cl}^{-}$concentration. This increase is likely due to a combination of the faster ion migration under higher solution conductivity and the depassivation effect of the chloride ion $[29,33,68]$. Nonetheless, excessive supporting electrolytes increases the risk of infringing on the emission restrictions. Based on a consideration for both energy consumption and removal efficiency, a minimum concentration of supporting electrolyte can be determined.

Energy consumption is directly proportional to the current density applied at a certain solution conductivity. When treating the water sample with the initial $\mathrm{Tl}(\mathrm{I})$ concentration of $115 \mu \mathrm{g} / \mathrm{L}$ at current densities of $8.3,16.7,25$, and $33.3 \mathrm{~mA} / \mathrm{cm}^{2}$, the energy consumption is $0.27,0.41,0.58$, and $0.98 \mathrm{kWh} / \mathrm{m}^{3}$, respectively, to reduce the residual concentration of $\mathrm{Tl}(\mathrm{I})$ to less than $5 \mu \mathrm{g} / \mathrm{L}$. Applying a current density of $16.7 \mathrm{~mA} / \mathrm{cm}^{2}$, the energy consumption to achieve a residual $\mathrm{Tl}(\mathrm{I})$ concentration of $2 \mu \mathrm{g} / \mathrm{L}$ is doubled to $0.82 \mathrm{kWh} / \mathrm{m}^{3}$. Another factor related to the operating costs is the consumption of sacrificial iron anodes. the iron consumption was $154.3 \mathrm{~g} / \mathrm{m}^{3}$ to achieve a residual $\mathrm{Tl}(\mathrm{I})$ concentration of $2 \mu \mathrm{g} / \mathrm{L}$ with the initial $\mathrm{Tl}(\mathrm{I})$ concentration of $115 \mu \mathrm{g} / \mathrm{L}$ at a current density of $16.7 \mathrm{~mA} / \mathrm{cm}^{2}$. However, due to the rapid removal of $\mathrm{Tl}(\mathrm{I})$, the consumption of the EC treatment is acceptable compared to traditional chemical precipitation methods. The $\mathrm{Fe}^{0}$-EC treatment is likely to be a potential economical industrial application for $\mathrm{Tl}(\mathrm{I})$ removal from industrial wastewater. 


\subsection{Effect of Tl(I) Initial Concentration}

$\mathrm{Fe}^{0}$-EC treatment of wastewater samples with initial $\mathrm{Tl}(\mathrm{I})$ concentrations of $66,115,141$, and $165 \mu \mathrm{g} / \mathrm{L}$, which are within the normal concentration range, was carried out at the current density of $16.7 \mathrm{~mA} / \mathrm{cm}^{2}$ (Figure S5). This showed that the $\mathrm{Tl}(\mathrm{I})$ removal processes exhibit a similar tendency for samples with different initial concentrations. Higher initial concentration brings higher removal efficiency, which is more pronounced in the early operation stage [64,68]. Nonetheless, longer EC operation time is required to achieve the same residual concentration when treating samples with higher initial concentration. The operation times obtained by interpolation were 4.43, 5.30, 5.86, and $6.13 \mathrm{~min}$ after the residual concentration reached $5 \mu \mathrm{g} / \mathrm{L}$ at the initial concentrations of $66,115,141$, and $165 \mu \mathrm{g} / \mathrm{L}$, respectively.

In order to evaluate the removal effect at higher $\mathrm{Tl}(\mathrm{I})$ concentration, solutions with initial $\mathrm{Tl}(\mathrm{I})$ concentrations of $0.66,10$, and $17.3 \mathrm{mg} / \mathrm{L}$ were concocted by replenishing $\mathrm{TlNO}_{3}(99.9 \%$, Sigma-Aldrich) into real wastewater for further EC treatment in the same reactor. Compared with treating wastewater with initial concentrations at the microgram level, the $\mathrm{Fe}^{0}$-EC removal of milligram $\mathrm{Tl}(\mathrm{I})$ concentrations from water samples observes the same removal rule (Figure S6).

\subsection{Removal Mechanism}

Generally, iron oxides/hydroxides can remove pollutants such as heavy metals, colloidal or solid particles, as well as soluble inorganic pollutants through either complexation or electrostatic attraction [27]. Due to its low hydration energy, $\mathrm{Tl}(\mathrm{I})$ is one of the few cations with specific adsorption capacity [69]. There is obvious $\mathrm{Tl}(\mathrm{I})$ sorption onto $\alpha$-FeOOH at $\mathrm{pH}$ values of less than 9.3, the PZC of $\alpha$-FeOOH [70] indicated that, besides deriving exospheric complexes induced by electrostatic attraction, $\mathrm{Tl}(\mathrm{I})$ is inclined to form stable inner-sphere complexes on iron oxides/hydroxides. In addition, studies have proved that the adsorption mechanism of $\mathrm{Tl}(\mathrm{I})$ on amorphous manganese oxide also fit the inner-sphere complexes model [71].

In order to investigate the mechanism of $\mathrm{Tl}(\mathrm{I})$ removal, the adsorption characteristics of different flocs at different $\mathrm{pH}$ values were studied using the suspension effluent as feed water. The suspension effluents were obtained after 20 min EC treatment at an initial $\mathrm{pH}$ of 7 and 11 . The suspension $\mathrm{pH}$ was adjusted by adding concentrated $\mathrm{HCl}$ or $\mathrm{NaOH}$. As shown in Figure S7, with the decrease of $\mathrm{pH}$ value, the $\mathrm{Tl}(\mathrm{I})$ concentration in the effluent increased gradually, indicating that the adsorption efficiency of feroxyhyte decreases with the decrease of the $\mathrm{pH}$ value. Nonetheless, $60.9 \% \mathrm{Tl}$ (I) was captured when the solution $\mathrm{pH}$ was lower than the PZC, which may suggest that the formation of the ligand is possible in the process of $\mathrm{Tl}(\mathrm{I})$ removal by EC treatment. Similarly, by increasing the $\mathrm{pH}$ of the effluent, the adsorption efficiency of lepidocrocite increased, which can be partly attributed to the electrostatic attraction.

Figure 6 shows the XPS spectra of flocculent sludge from $\mathrm{Fe}^{0}$-EC treatment of Tl-containing wastewater and blank water samples. Fe $2 \mathrm{p}_{1 / 2}$ and $\mathrm{Fe} 2 \mathrm{p}_{3 / 2}$ peaks appeared respectively at $724.39 \mathrm{eV}$ and $710.99 \mathrm{eV}$ on both spectra in Figure 6a, showing the characteristics of $\mathrm{Fe}^{3+}$ [72]. This is consistent with our chemical analysis of different valence iron contents in flocculent sludges (Table S1). It can be concluded that, amid this $\mathrm{Tl}(\mathrm{I})$ adsorption process, the chemical state of Fe did not change as the Fe $2 p$ peaks have almost identical shape and centroid. On the spectrum (Figure $6 \mathrm{~b}$ ) of flocculent sludge collected from $\mathrm{Fe}^{0}$-EC processed wastewater, two peaks of $\mathrm{Tl} 4 \mathrm{f}$, i.e., $4 \mathrm{f} 7 / 2$ and $4 \mathrm{f} 5 / 2$, appeared at 118.69 and $123.09 \mathrm{eV}$. The XPS peaks show a characteristic of $\mathrm{Tl}(\mathrm{I})$ [71], which verified the chemical state of $\mathrm{Tl}$ in the processing circumstances is $\mathrm{Tl}(\mathrm{I})$. It can be concluded that there is no $\mathrm{Tl}(\mathrm{I})$ that was oxidized and thereby no surface precipitation effect on the $\mathrm{Tl}$ removal by the $\mathrm{Fe}^{0}-\mathrm{EC}$ treatment. Figure $6 \mathrm{c}$ shows the $\mathrm{O} 1 \mathrm{~s}$ peak in the range of $527-534 \mathrm{eV}$. The $\mathrm{O} 1 \mathrm{~s}$ peak at $529.89 \mathrm{eV}$ is typical for oxygen bonded to transition metal [73], namely, Fe-O in this study. The second peak at $531.24 \mathrm{eV}$ can be assigned to the -OH group with higher binding energy [73]. It is observed that after capturing $\mathrm{Tl}(\mathrm{I})$, the integral area of the -OH group increased significantly. This can be attributed to the decrease of electron cloud density on oxygen, since electrons surrounding the oxygen of the deprotonated 
hydroxyl were attracted by Tl(I) cations. These XPS spectra indicate the successful capturing of Tl(I) by feroxyhyte owing to the interaction of surface hydroxyl and $\mathrm{Tl}(\mathrm{I})$.
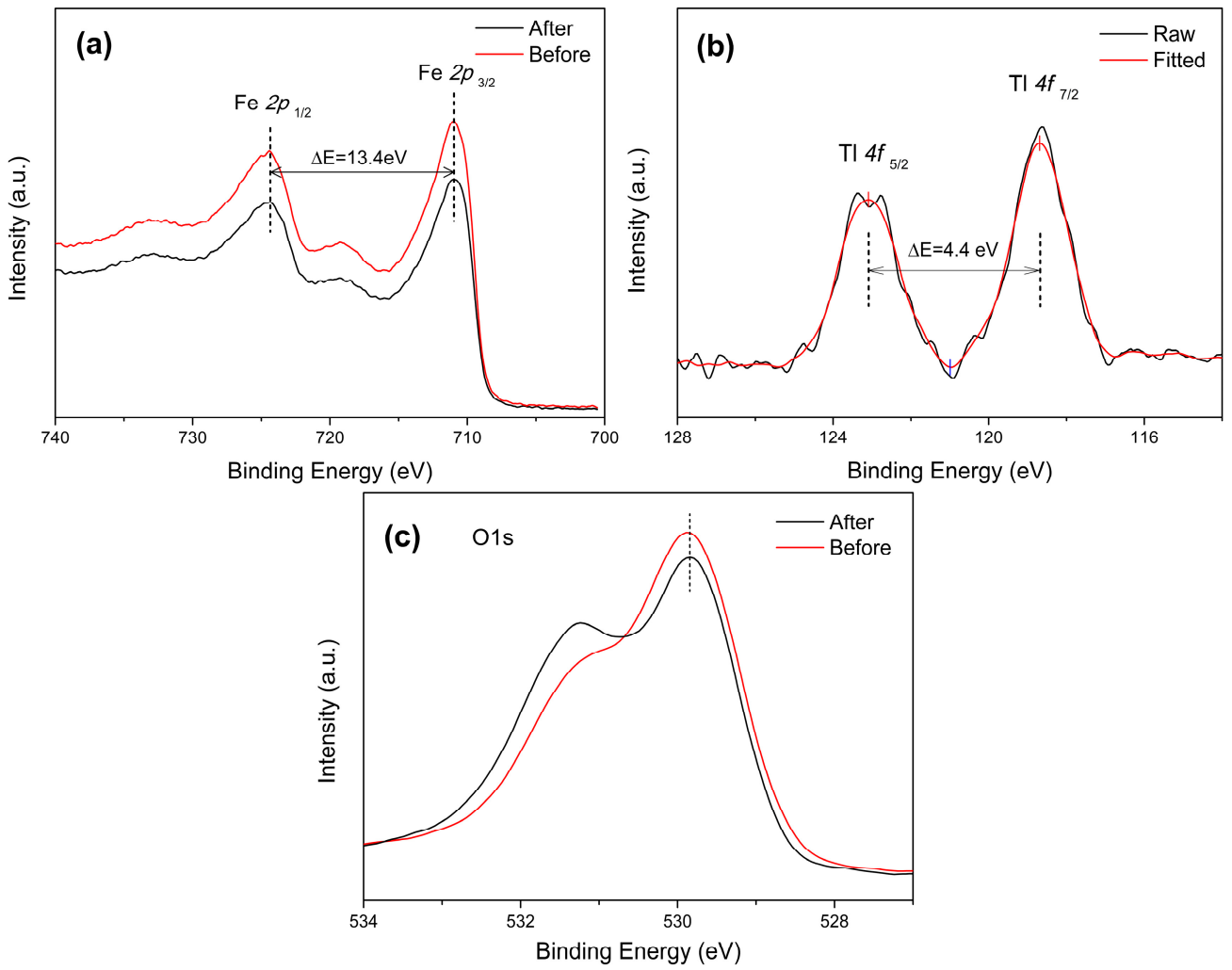

Figure 6. X-ray photoelectron spectroscopy (XPS) spectra of flocculent sludge obtained under applied current density of $16.7 \mathrm{~mA} / \mathrm{cm}^{2}$ at initial $\mathrm{pH}$ of 11: (a) Fe 2p core level; (b) Tl $4 \mathrm{f}$ core level; (c) O 1s core level.

According to the above discussion, it can be concluded that the $\mathrm{Fe}^{0}$-EC removal of $\mathrm{Tl}(\mathrm{I})$ is actualized by the combined effect of two mechanisms. Figure 7 shows the schematic diagram of the possible removal pathways of $\mathrm{Tl}(\mathrm{I})$ during the $\mathrm{Fe}^{0}$-EC process. The $\mathrm{Tl}(\mathrm{I})$ removal efficiency of both feroxyhyte and lepidocrocite is $\mathrm{pH}$-dependent when treating water samples with a $\mathrm{pH}$ higher than the $\mathrm{PZC}$, which indicates that the adsorption of $\mathrm{Tl}(\mathrm{I})$ on negatively charged $\mathrm{FeOOH}$ is induced by electrostatic attraction. Meanwhile, both FeOOH samples can still absorb respectively $60.9 \%$ and $22.4 \% \mathrm{Tl}$ (I) (Figure S7) at a $\mathrm{pH}$ of 7 (below PZC), showing the existence of inner-sphere complexes, as proved by the XPS results.

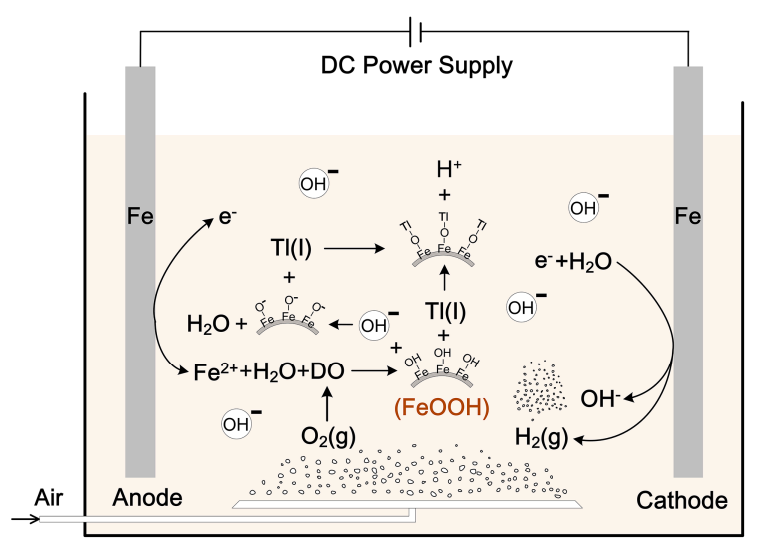

Figure 7. Schematic diagram of the removal pathways of $\mathrm{Tl}(\mathrm{I})$ during the $\mathrm{Fe}^{0}$-EC process. 


\section{Conclusions}

The $\mathrm{Fe}^{0}$-EC process with aeration can be applied for effective $\mathrm{Tl}(\mathrm{I})$ removal from real industrial wastewater. Initial $\mathrm{pH}$ and $\mathrm{DO}$ concentration were indicated to be the key operation parameters for $\mathrm{Tl}(\mathrm{I})$ removal. Iron oxyhydroxides with different crystal structure were obtained from $\mathrm{Fe}^{0}$-EC processed water with different initial $\mathrm{pH}$ values. A slow oxidation rate and neutral $\mathrm{pH}$ benefit the forming of lepidocrocite, while rapid oxidation under DO-rich conditions is the key factor for feroxyhyte formation. Nanosheet-structured feroxyhyte with large specific surface area generated in situ is an important factor for rapid and effective $\mathrm{Tl}(\mathrm{I})$ removal. The mechanism for $\mathrm{Tl}(\mathrm{I})$ removal by $\mathrm{Fe}^{0}-\mathrm{EC}$ is attributed to the combination of exospheric complexes formed by electrostatic attraction under alkaline $\mathrm{pH}$ and the formation of inner-sphere complexes with active groups of iron oxides/hydroxides.

The lab-scaled batch aeration-forced pump cycle EC reaction system is easily converted to continuous reaction mode. A pilot scale experiment operating in continuous mode is already under way to evaluate the industrial feasibility of $\mathrm{Tl}(\mathrm{I})$ removal from wastewater by EC technology.

Supplementary Materials: The following are available online at http://www.mdpi.com/2073-4441/12/1/163/s1. Figure S1: Effect of electrode material on Tl(I) removal efficiency within 20 min EC treatment under applied current density of $16.7 \mathrm{~mA} / \mathrm{cm}^{2}$ with initial $\mathrm{pH}$ of $11 \pm 0.1$, electrodes distance of $2 \mathrm{~cm}, \mathrm{C}_{0}=109 \mu \mathrm{g} / \mathrm{L}$. Figure S2: Effect of $\mathrm{pH}$ on $\mathrm{Mg}$ removal efficiency within $20 \mathrm{~min} \mathrm{EC}$ treatment under applied current density of $16.7 \mathrm{~mA} / \mathrm{cm}^{2}$, using Fe-Fe electrodes at distance of $2 \mathrm{~cm}, \mathrm{C}_{0}=41.5 \mathrm{mg} / \mathrm{L}$. Figure S3: Effect of $\mathrm{pH}$ on $\mathrm{Tl}(\mathrm{I})$ removal efficiency of the as-prepared $\mathrm{FeOOH}$. Adsorbent dose $0.44 \mathrm{~g} / \mathrm{L}$, agitation speed at $100 \mathrm{rpm}$ for 4 hours at room temperature $\left(25^{\circ} \mathrm{C}\right)$, $\mathrm{C}_{0}=141 \mu \mathrm{g} / \mathrm{L}$. Figure S4: Effect of $\mathrm{Cl}^{-}$concentration on Tl(I) removal efficiency within 20 min EC treatment under applied current density of $16.7 \mathrm{~mA} / \mathrm{cm}^{2}$, initial $\mathrm{pH}$ of $11 \pm 0.1$, using Fe-Fe electrodes at distance of $2 \mathrm{~cm}$, $\mathrm{C}_{0}=95 \mu \mathrm{g} / \mathrm{L}$. Figure S5: Effect of initial Tl(I) concentration on $\mathrm{Tl}(\mathrm{I})$ removal efficiency within $20 \mathrm{~min} \mathrm{EC}$ treatment under initial $\mathrm{pH}$ of $11 \pm 0.1$ with aeration of $0.2 \mathrm{~L} / \mathrm{min}$, using Fe-Fe electrodes at distance of $2 \mathrm{~cm}, \mathrm{C}_{0}=66,115,141$, $165 \mu \mathrm{g} / \mathrm{L}$, respectively. Figure S6: Removal efficiency of high Tl(I) concentration within 60 min EC treatment under initial $\mathrm{pH}$ of $11 \pm 0.1$ with aeration of $0.2 \mathrm{~L} / \mathrm{min}$, using Fe-Fe electrodes at distance of $2 \mathrm{~cm}, \mathrm{C}_{0}=660,10,000$ and $17,300 \mu \mathrm{g} / \mathrm{L}$, respectively. Figure S7: Effect of $\mathrm{pH}$ on Tl(I) removal efficiency of effluent after 20 min EC treatment under applied current density of $16.7 \mathrm{~mA} / \mathrm{cm}^{2}$ with aeration of $0.2 \mathrm{~L} / \mathrm{min}$. using Fe-Fe electrodes at distance of $2 \mathrm{~cm}$. Initial $\mathrm{pH}$ of 7 and 11, respectively. Table S1: The content of $\mathrm{Fe}^{3+}$ and $\mathrm{TFe}(\mathrm{wt} . \%)$ in flocculent sludges obtained at vary initial $\mathrm{pH}$. Table S2: The specific surface area, average pore size and pore volume of flocculent sludges obtained at vary initial $\mathrm{pH}$.

Author Contributions: Conceptualization, X.F. and G.Y.; methodology, X.F.; validation, X.F. and X.X.; investigation, X.F., G.Y. and L.L.; resources, L.H.; writing-original draft preparation, X.F.; writing-review and editing, X.F. and X.X.; supervision, Z.Z. All authors have read and agreed to the published version of the manuscript.

Funding: This research was jointly supported by the National Key Research and Development Program of 13th Five-year Plan (No. 2016YFC0304105-03) and the Science and Technology Innovation Projects of Changsha Research Institute of Mining and Metallurgy (2018HB-A5-01).

Conflicts of Interest: The authors declare no conflict of interest.

\section{References}

1. Galván-Arzate, S.; Santamaría, A. Thallium toxicity. Toxicol. Lett. 1998, 99, 1-13. [CrossRef]

2. Peter, A.L.; Viraraghavan, T. Thallium: A review of public health and environmental concerns. Environ. Int. 2005, 31, 493-501. [CrossRef]

3. Xiao, T.; Yang, F.; Li, S.; Zheng, B.; Ning, Z. Thallium pollution in China: A geo-environmental perspective. Sci. Total Environ. 2012, 421-422, 51-58. [CrossRef] [PubMed]

4. US EPA. Effluent Guidelines-Toxic and Priority Pollutants under the Clean Water Act; Agency, E.P., Ed.; US EPA: Washington, DC, USA, 2015; p. 2. Available online: https:/www.epa.gov/sites/production/files/2015-09/ documents/priority-pollutant-list-epa.pdf (accessed on 17 October 2019).

5. Commissie Eu. Directive 2000/60/EC of the European Parliament and of the Council of 23 October 2000 establishing a framework for Community action in the field of water policy. Off. J. Eur. Communities 2000, 1-72. Available online: https://eur-lex.europa.eu/eli/dir/2000/60/oj (accessed on 17 October 2019).

6. MEE; PRC. The 12th Five-Year Plan for Comprehensive Prevention and Control of Heavy Metals Pollution; MEE, PRC, Eds.; General office of the Ministry Ministry of Ecology and Environment of the PRC: Beijing, China, 2011. 
7. Xu, H.; Luo, Y.; Wang, P.; Zhu, J.; Yang, Z.; Liu, Z. Removal of thallium in water/wastewater: A review. Water Res. 2019, 165, 114981. [CrossRef]

8. Perotti, M.; Petrini, R.; D'Orazio, M.; Ghezzi, L.; Giannecchini, R.; Vezzoni, S. Thallium and other potentially toxic elements in the baccatoio stream catchment (northern tuscany, italy) receiving drainages from abandoned mines. Mine Water Environ. 2018, 37, 431-441. [CrossRef]

9. Almassri, I.; Sekkarie, M. Cases of thallium intoxication in syria: A diagnostic and a therapeutic challenge. Avicenna J. Med. 2018, 8, 78-81. [CrossRef]

10. Cheam, V. Thallium contamination of water in canada. Water Qual. Res. J. Can. 2001, 36, 851-877. [CrossRef]

11. Belzile, N.; Chen, Y.-W. Thallium in the environment: A critical review focused on natural waters, soils, sediments and airborne particles. Appl. Geochem. 2017, 84, 218-243. [CrossRef]

12. Kaplan, D.I.; Mattigod, S.V. Aqueous geochemistry of thallium. Adv. Environ. Sci. Technol. N. Y. 1998, 29, 15-30.

13. Delvalls, T.; Saenz, V.; Arias, A.M.; Blasco, J. Thallium in the marine environment: First ecotoxicological assessments in the guadalquivir estuary and its potential adverse effect on the donana european natural reserve after the aznalcóllar mining spill (sw spain). Cienc. Mar. 1999, 25, 161-175. [CrossRef]

14. Vink, B. The behaviour of thallium in the (sub) surface environment in terms of Eh and pH. Chem. Geol. 1993, 109, 119-123. [CrossRef]

15. Zhang, L.; Huang, T.; Zhang, M.; Guo, X.; Yuan, Z. Studies on the capability and behavior of adsorption of thallium on nano- $\mathrm{Al}_{2} \mathrm{O}_{3}$. J. Hazard. Mater. 2008, 157, 352-357. [CrossRef] [PubMed]

16. Li, H.; Chen, Y.; Long, J.; Li, X.; Jiang, D.; Zhang, P.; Qi, J.; Huang, X.; Liu, J.; Xu, R.; et al. Removal of thallium from aqueous solutions using Fe-Mn binary oxides. J. Hazard. Mater. 2017, 338, 296-305. [CrossRef]

17. Zhang, G.; Fan, F.; Li, X.; Qi, J.; Chen, Y. Superior adsorption of thallium(I) on titanium peroxide: Performance and mechanism. Chem. Eng. J. 2018, 331, 471-479. [CrossRef]

18. Chen, M.; Wu, P.; Yu, L.; Liu, S.; Ruan, B.; Hu, H.; Zhu, N.; Lin, Z. FeOOH-loaded $\mathrm{MnO}_{2}$ nano-composite: An efficient emergency material for thallium pollution incident. J. Environ. Manag. 2017, 192, 31-38. [CrossRef]

19. Li, H.; Li, X.; Long, J.; Li, K.; Chen, Y.; Jiang, J.; Chen, X.; Zhang, P. Oxidation and removal of thallium and organics from wastewater using a zero-valent-iron-based fenton-like technique. J. Clean. Prod. 2019, 221, 89-97. [CrossRef]

20. Davies, M.; Figueroa, L.; Wildeman, T.; Bucknam, C. The oxidative precipitation of thallium at alkaline $\mathrm{pH}$ for treatment of mining influenced water. Mine Water Environ. 2016, 35, 77-85. [CrossRef]

21. Yang, L.; Xiao, J.; Shen, Y.; Liu, X.; Li, W.; Wang, W.; Yang, Y. The efficient removal of thallium from sintering flue gas desulfurization wastewater in ferrous metallurgy using emulsion liquid membrane. Environ. Sci. Pollut. Res. Int. 2017, 24, 24214-24222. [CrossRef]

22. Li, H.; Chen, Y.; Long, J.; Jiang, D.; Liu, J.; Li, S.; Qi, J.; Zhang, P.; Wang, J.; Gong, J.; et al. Simultaneous removal of thallium and chloride from a highly saline industrial wastewater using modified anion exchange resins. J. Hazard. Mater. 2017, 333, 179-185. [CrossRef]

23. Liu, Y.; Wang, L.; Wang, X.; Huang, Z.; Xu, C.; Yang, T.; Zhao, X.; Qi, J.; Ma, J. Highly efficient removal of trace thallium from contaminated source waters with ferrate: Role of in situ formed ferric nanoparticle. Water Res. 2017, 124, 149-157. [CrossRef]

24. MEE; PRC. Explanation on Compilation of Amendment List of "Emission Standare of Pollutantss for Lead and Zinc Industry" (GB 25466-2010) (Draft for Comment); MEE, PRC, Eds.; General office of the Ministry Ministry of Ecology and Environment of the PRC: Beijing, China, 2018. Available online: http://www.mee.gov.cn/gkml/ sthjbgw/stbgth/201809/W020180926341528139268.pdf (accessed on 17 October 2019).

25. Liu, J.; Wang, J.; Chen, Y.; Lippold, H.; Xiao, T.; Li, H.; Shen, C.-C.; Xie, L.; Xie, X.; Yang, H. Geochemical transfer and preliminary health risk assessment of thallium in a riverine system in the pearl river basin, south China. J. Geochem. Explor. 2017, 176, 64-75. [CrossRef]

26. Li, H.; Zhang, H.; Long, J.; Zhang, P.; Chen, Y. Combined fenton process and sulfide precipitation for removal of heavy metals from industrial wastewater: Bench and pilot scale studies focusing on in-depth thallium removal. Front. Environ. Sci. Eng. 2019, 13, 49. [CrossRef]

27. Mollah, M.Y.A.; Schennach, R.; Parga, J.R.; Cocke, D.L. Electrocoagulation (EC)-science and applications. J. Hazard. Mater. 2001, 84, 29-41. [CrossRef] 
28. Mollah, M.Y.; Morkovsky, P.; Gomes, J.A.; Kesmez, M.; Parga, J.; Cocke, D.L. Fundamentals, present and future perspectives of electrocoagulation. J. Hazard. Mater. 2004, 114, 199-210. [CrossRef] [PubMed]

29. Moussa, D.T.; El-Naas, M.H.; Nasser, M.; Al-Marri, M.J. A comprehensive review of electrocoagulation for water treatment: Potentials and challenges. J. Environ. Manag. 2017, 186, 24-41. [CrossRef]

30. Moreno-Casillas, H.A.; Cocke, D.L.; Gomes, J.A.G.; Morkovsky, P.; Parga, J.R.; Peterson, E. Electrocoagulation mechanism for COD removal. Sep. Purif. Technol. 2007, 56, 204-211. [CrossRef]

31. Brillas, E.; Martínez-Huitle, C.A. Decontamination of wastewaters containing synthetic organic dyes by electrochemical methods. An updated review. Appl. Catal. B 2015, 166-167, 603-643. [CrossRef]

32. Yavuz, Y.; Ogutveren, U.B. Treatment of industrial estate wastewater by the application of electrocoagulation process using iron electrodes. J. Environ. Manag. 2018, 207, 151-158. [CrossRef]

33. Tezcan Un, U.; Onpeker, S.E.; Ozel, E. The treatment of chromium containing wastewater using electrocoagulation and the production of ceramic pigments from the resulting sludge. J. Environ. Manag. 2017, 200, 196-203. [CrossRef]

34. Gilhotra, V.; Das, L.; Sharma, A.; Kang, T.S.; Singh, P.; Dhuria, R.S.; Bhatti, M.S. Electrocoagulation technology for high strength arsenic wastewater: Process optimization and mechanistic study. J. Clean Prod. 2018, 198, 693-703. [CrossRef]

35. Khatibikamal, V.; Torabian, A.; Janpoor, F.; Hoshyaripour, G. Fluoride removal from industrial wastewater using electrocoagulation and its adsorption kinetics. J. Hazard. Mater. 2010, 179, 276-280. [CrossRef] [PubMed]

36. Wan, W.; Pepping, T.J.; Banerji, T.; Chaudhari, S.; Giammar, D.E. Effects of water chemistry on arsenic removal from drinking water by electrocoagulation. Water Res. 2011, 45, 384-392. [CrossRef] [PubMed]

37. Fuente, A.D.L.; Muro-Pastor, A.M.; Merchán, F.; Madrid, F.; Pérez-Martínez, J.I.; Undabeytia, T. Electrocoagulation/flocculation of cyanobacteria from surface waters. J. Clean Prod. 2019, 238. [CrossRef]

38. Huangfu, X.; Ma, C.; Ma, J.; He, Q.; Yang, C.; Jiang, J.; Wang, Y.; Wu, Z. Significantly improving trace thallium removal from surface waters during coagulation enhanced by nanosized manganese dioxide. Chemosphere 2017, 168, 264-271. [CrossRef] [PubMed]

39. Wang, W.; Zhou, J.; Achari, G.; Yu, J.; Cai, W. Cr(VI) removal from aqueous solutions by hydrothermal synthetic layered double hydroxides: Adsorption performance, coexisting anions and regeneration studies. Colloids Surf. A 2014, 457, 33-40. [CrossRef]

40. Coup, K.M.; Swedlund, P.J. Demystifying the interfacial aquatic geochemistry of thallium(I): New and old data reveal just a regular cation. Chem. Geol. 2015, 398, 97-103. [CrossRef]

41. Katal, R.; Pahlavanzadeh, H. Influence of different combinations of aluminum and iron electrode on electrocoagulation efficiency: Application to the treatment of paper mill wastewater. Desalination 2011, 265, 199-205. [CrossRef]

42. Golder, A.K.; Chanda, A.K.; Samanta, A.N.; Ray, S. Removal of hexavalent chromium by electrochemical reduction-precipitation: Investigation of process performance and reaction stoichiometry. Sep. Purif. Technol. 2011, 76, 345-350. [CrossRef]

43. Al-Shannag, M.; Al-Qodah, Z.; Bani-Melhem, K.; Qtaishat, M.R.; Alkasrawi, M. Heavy metal ions removal from metal plating wastewater using electrocoagulation: Kinetic study and process performance. Chem. Eng. J. 2015, 260, 749-756. [CrossRef]

44. Malakootian, M.; Mansoorian, H.J.; Moosazadeh, M. Performance evaluation of electrocoagulation process using iron-rod electrodes for removing hardness from drinking water. Desalination 2010, 255, 67-71. [CrossRef]

45. Hakizimana, J.N.; Gourich, B.; Chafi, M.; Stiriba, Y.; Vial, C.; Drogui, P.; Naja, J. Electrocoagulation process in water treatment: A review of electrocoagulation modeling approaches. Desalination 2017, 404, 1-21. [CrossRef]

46. Arroyo, M.G.; Perez-Herranz, V.; Montanes, M.T.; Garcia-Anton, J.; Guinon, J.L. Effect of pH and chloride concentration on the removal of hexavalent chromium in a batch electrocoagulation reactor. J. Hazard. Mater. 2009, 169, 1127-1133. [CrossRef] [PubMed]

47. Chen, G. Electrochemical technologies in wastewater treatment. Sep. Purif. Technol. 2004, 38, 11-41. [CrossRef]

48. Xiong, Y. The aqueous geochemistry of thallium: Speciation and solubility of thallium in low temperature systems. Environ. Chem. 2009, 6, 441-451. [CrossRef] 
49. Khoo, K.H.; Fernando, K. Solubility and activity coefficient of thallium (I) chloride in the system $\mathrm{TlCl}+\mathrm{HCl}+$ $\mathrm{NaCl}+\mathrm{H}_{2} \mathrm{O}$ at $25^{\circ} \mathrm{C}$. J. Solut. Chem. 1991, 20, 1199-1211. [CrossRef]

50. Liu, J.; Luo, X.; Sun, Y.; Tsang, D.C.W.; Qi, J.; Zhang, W.; Li, N.; Yin, M.; Wang, J.; Lippold, H.; et al. Thallium pollution in China and removal technologies for waters: A review. Environ. Int. 2019, 126, 771-790. [CrossRef]

51. Schwertmann, U.; Fechter, H. The point of zero charge of natural and synthetic ferrihydrites and its relation to adsorbed silicate. Clay Miner. 1982, 17, 471-476. [CrossRef]

52. Faria, M.C.S.; Rosemberg, R.S.; Bomfeti, C.A.; Monteiro, D.S.; Barbosa, F.; Oliveira, L.C.A.; Rodriguez, M.; Pereira, M.C.; Rodrigues, J.L. Arsenic removal from contaminated water by ultrafine $\delta$-FeOOH adsorbents. Chem. Eng. J. 2014, 237, 47-54. [CrossRef]

53. Yang, Z.-H.; Xu, H.-Y.; Zeng, G.-M.; Luo, Y.-L.; Yang, X.; Huang, J.; Wang, L.-K.; Song, P.-P. The behavior of dissolution/passivation and the transformation of passive films during electrocoagulation: Influences of initial pH, Cr(VI) concentration, and alternating pulsed current. Electrochim. Acta 2015, 153, 149-158. [CrossRef]

54. Lakshmanan, D.; Clifford, D.A.; Samanta, G. Ferrous and ferric ion generation during iron electrocoagulation. Environ. Sci. Technol. 2009, 43, 3853-3859. [CrossRef] [PubMed]

55. Chukhrov, F.V.; Zvyagin, B.B.; Gorshkov, A.I.; Yermilova, L.P.; Korovushkin, V.V.; Rudnitskaya, Y.S.; Yakubovskaya, N.Y. Feroxyhyte, a new modification of FeOOH. Int. Geol. Rev. 1977, 19, 873-890. [CrossRef]

56. Schwertmann, U.; Cornell, R.M. Iron Oxides in the Laboratory: Preparation and Characterization; John Wiley \& Sons: New York, NY, USA, 2008.

57. Ben Sasson, M.; Calmano, W.; Adin, A. Iron-oxidation processes in an electroflocculation (electrocoagulation) cell. J. Hazard. Mater. 2009, 171, 704-709. [CrossRef] [PubMed]

58. Rahimi, S.; Moattari, R.M.; Rajabi, L.; Derakhshan, A.A.; Keyhani, M. Iron oxide/hydroxide $(\alpha, \gamma-\mathrm{FeOOH})$ nanoparticles as high potential adsorbents for lead removal from polluted aquatic media. J. Ind. Eng. Chem. 2015, 23, 33-43. [CrossRef]

59. Stumm, W.; Lee, G.F. Oxygenation of ferrous iron. Ind. Eng. Chem. 1961, 53, 143-146. [CrossRef]

60. Morgan, B.; Lahav, $\mathrm{O}$. The effect of $\mathrm{pH}$ on the kinetics of spontaneous $\mathrm{Fe}(\mathrm{II})$ oxidation by $\mathrm{O}_{2}$ in aqueous solution-basic principles and a simple heuristic description. Chemosphere 2007, 68, 2080-2084. [CrossRef]

61. Pedersen, H.D.; Postma, D.; Jakobsen, R.; Larsen, O. Fast transformation of iron oxyhydroxides by the catalytic action of aqueous Fe(II). Geochim. Cosmochim. Acta 2005, 69, 3967-3977. [CrossRef]

62. Tamaura, Y.; Ito, K.; Katsura, T. Transformation of $\gamma-\mathrm{FeO}(\mathrm{OH})$ to $\mathrm{Fe}_{3} \mathrm{O}_{4}$ by adsorption of iron (II) ion on $\gamma$-FeO(OH). J. Chem. Soc. Dalton Trans. 1983, 189-194. [CrossRef]

63. Ruby, C.; Abdelmoula, M.; Naille, S.; Renard, A.; Khare, V.; Ona-Nguema, G.; Morin, G.; Génin, J.-M.R. Oxidation modes and thermodynamics of FeII-III oxyhydroxycarbonate green rust: Dissolution-precipitation versus in situ deprotonation. Geochim. Cosmochim. Acta 2010, 74, 953-966. [CrossRef]

64. Al Aji, B.; Yavuz, Y.; Koparal, A.S. Electrocoagulation of heavy metals containing model wastewater using monopolar iron electrodes. Sep. Purif. Technol. 2012, 86, 248-254. [CrossRef]

65. Kobya, M.; Demirbas, E.; Dedeli, A.; Sensoy, M.T. Treatment of rinse water from zinc phosphate coating by batch and continuous electrocoagulation processes. J. Hazard. Mater. 2010, 173, 326-334. [CrossRef] [PubMed]

66. Holt, P.K.; Barton, G.W.; Wark, M.; Mitchell, C.A. A quantitative comparison between chemical dosing and electrocoagulation. Colloids Surf. A 2002, 211, 233-248. [CrossRef]

67. El-Masry, M.H.; Sadek, O.M.; Mekhemer, W.K. Purification of raw surface water using electro-coagulation method. Water Air Soil Pollut. 2004, 158, 373-385. [CrossRef]

68. Chen, X.; Ren, P.; Li, T.; Trembly, J.P.; Liu, X. Zinc removal from model wastewater by electrocoagulation: Processing, kinetics and mechanism. Chem. Eng. J. 2018, 349, 358-367. [CrossRef]

69. Li, D. Principles of Electrochemistry, 3rd ed.; Beihang University Press: Beijing, China, 2008.

70. Liu, J.; Lippold, H.; Wang, J.; Lippmann-Pipke, J.; Chen, Y. Sorption of thallium(I) onto geological materials: Influence of $\mathrm{pH}$ and humic matter. Chemosphere 2011, 82, 866-871. [CrossRef]

71. Wan, S.; Ma, M.; Lv, L.; Qian, L.; Xu, S.; Xue, Y.; Ma, Z. Selective capture of thallium(I) ion from aqueous solutions by amorphous hydrous manganese dioxide. Chem. Eng. J. 2014, 239, 200-206. [CrossRef] 
72. Quan, H.; Cheng, B.; Xiao, Y.; Lei, S. One-pot synthesis of $\alpha$-Fe2O3 nanoplates-reduced graphene oxide composites for supercapacitor application. Chem. Eng. J. 2016, 286, 165-173. [CrossRef]

73. Biesinger, M.C.; Payne, B.P.; Grosvenor, A.P.; Lau, L.W.; Gerson, A.R.; Smart, R.S.C. Resolving surface chemical states in XPS analysis of first row transition metals, oxides and hydroxides: $\mathrm{Cr}, \mathrm{Mn}, \mathrm{Fe}, \mathrm{Co}$ and $\mathrm{Ni}$. Appl. Surf. Sci. 2011, 257, 2717-2730. [CrossRef]

(C) 2020 by the authors. Licensee MDPI, Basel, Switzerland. This article is an open access article distributed under the terms and conditions of the Creative Commons Attribution (CC BY) license (http://creativecommons.org/licenses/by/4.0/). 